\title{
A Triadic Actor View of Value Co-creation in Business Incubation
}

\author{
Ronald Beckett and John Dalrymple
}

\author{
"I think it's smart to always keep an eye on companies that sit within \\ incubator communities, which bring together the skills and expertise \\ needed to grow an enterprise. "
}

Whitney Wolfe Herd American entrepreneur

Founder of Bumble

\begin{abstract}
In this paper we view an incubator as a service entity that may take different forms. We contribute to the literature by exploring the utility of the service-dominant logic (SDL) paradigm (Vargo \& Lusch, 2016) to better understand incubation operations. Value cocreation is a central axiom of SDL, as is engagement with a supporting service ecosystem. Whilst some studies have considered dyadic incubator-client value creation arrangements, we extend this to include interaction with other service ecosystem stakeholders that we characterise as investors. This way a triadic interaction model is presented. We consider four different cases of a service entity supporting start-up development from this actor-oriented perspective. Adopting a client company perspective, we draw a parallel between various kinds of incubation services and department stores, where clients may access what they need when they need it from a variety of offerings, and obtain the assistance they require.
\end{abstract}

\section{Introduction}

The globalization of business, combined with technological and demographic changes, is impacting the world's regions in different ways. Nevertheless, a common response to emergent conditions is to encourage the establishment of new businesses (or the growth of established businesses), facilitated by some form of business startup incubation support. Some studies (Bruneel et al., 2012) have suggested that further research is needed to look beyond providing incubator service to also consider firstly, how regional conditions shape the incubator business model rationale, and secondly, the extent to which incubator value propositions and client profiles are aligned. In this paper, we take up these suggestions in our analysis.

In a previous study of two commercial incubators started by serial entrepreneurs, we utilized a business model view to characterize and compare them. We noted there were associated businesses investing in the incubator and that there was a good fit between the niche client groups chosen and regional strengths. Put another way, the business model view was useful but incomplete. In this paper, we consider additional matters of context.

The paper is organized as follows: from the literature review we frame the incubator as a service entity embedded in a service ecosystem that may take several forms. We contribute to the business incubation literature by adopting the service-dominant logic (SDL) paradigm (Vargo \& Lusch, 2016) to consider how value both is and may be delivered to investors in an incubator, as well as to incubator clients. This leads to our research question: how might an actor-centric view of incubation programs be used to draw out matters of context and practice? We present a model with a triadic view (investor, incubator, incubatee) of value cocreation and illustrate its utility by drawing on four case studies. 


\section{A Triadic Actor View of Value Co-creation in Business Incubation Ronald Beckett and John Dalrymple}

\section{Some Observations from the Literature}

Incubators, incubation support processes and supporting ecosystems

Fernández Fernández et al. (2015) considered business incubation "as an evolving and interactive process of the provision of value-added services within an entrepreneurship ecosystem". They identified some patterns of service provision that were conditioned by ownership, scale, partnership activities, and the effectiveness of cooperation with private, public, and university sectors. Autio et al. (2014) stressed the importance of context in stimulating entrepreneurial innovation, including the experience level of the entrepreneur and a supportive ecosystem. Valkokari (2015) suggested that enterprises of all kinds are embedded in broader business, innovation, and knowledge ecosystems. Engagement with such ecosystems can provide access to complementary resources, while each encounter differs in terms of its outcomes, interactions, logic of action (rules of the game), and actor roles.

A study by the UK innovation foundation, NESTA, examined the question: how do support programs fulfil different roles for startups within startup ecosystems? (Dee et al, 2015). The study observed that what had become known as 'incubation' meant not just the services provided by a self-identified 'incubator', but rather was an umbrella term for a range of startup programs. Terms used for programs included accelerators, coworking spaces, active seed investors, courses, competitions, and others. It was suggested that incubation programs could be differentiated in the market by how they made money from startups, and when programmes intervened in a startup's origin story and development. Potential sources of revenue identified were rent, membership fees, service fees, equity, \% of earnings, sponsorship, public funding, introduction fees, events and catering. In terms of intervention points, it has been broadly observed that entrepreneurs need different kinds of support as their enterprise grows from a fragile startup to one with significant growth potential. Likewise, some kinds of incubator may specialize in supporting a particular stage of startup development. The NESTA research, which considered incubation activities in Germany, the UK, and Israel, also suggested there were links between how developed an ecosystem was and the likely success of innovation programs.
It is suggested in the literature (Von Zedtwitz \& Grimaldi, 2006: Bruneel et al, 2012) that an incubator may be classified according to its 'business model'. Currently on offer are university, regional, commercial, company-internal, and virtual models. Chase and Webb (2018) conducted a multinational study of incubator and accelerator business models on behalf of Saudi Arabian and Australian business and government interests. They suggested that financial independence for incubators and accelerators was unlikely, that their continued operations relied on some external form of government or corporate support, and that in many regions the investment of time by volunteer mentors, accountants, legal advisors, and other professions was needed and could help reduce financial requirements.

\section{The concept of value co-creation}

Supplier-customer value co-creation practices are widely reported in the management literature, and may relate to co-production, for example, the development of enhanced value propositions or new product requirements, or to value-in-use: the customer's experiential evaluation of the product or service proposition beyond its functional attributes (Ranjan \& Reed, 2016). Rice (2002) viewed a business incubator as a producer of support programs developed in conjunction with the community it is embedded in. It was noted that both parties bring knowledge to the coproduction relationship and that time available for coproduction was a significant influencing factor.

Eriksson et al. (2014) saw business incubation as a process where a service entity sought to orchestrate collaboration with other actors. They noted that prior research on incubation concentrated on a dyadic relationship between incubation actors and their clients. They also explored an alternative view of microlevel activities that considered engagement with other actors (customers of the clients and technology researchers), finding that mutual trust was seen as a prerequisite for active collaboration.

Hughes et al., (2007) argued that while incubators offer opportunities for value creation, how client firms chose to use them dictates the extent to which value by 'incubation' is realised. Their research identified two value-stimulating behaviours: resource pooling (resource-seeking behaviour) and strategic network involvement (knowledge-seeking behaviour). Drawing on responses from a survey of 211 UK incubator client 


\section{A Triadic Actor View of Value Co-creation in Business Incubation Ronald Beckett and John Dalrymple}

firms they characterised four different client practices:

- enclosed incubation, where a firm undertakes very limited resource pooling and network involvement to protect their intellectual assets.

- specialised incubation, where the firm undertakes extensive resource pooling, but only limited knowledge-based interactions. These firms may link complementary assets, while seeing little value in sharing knowledge.

- community incubation, where a firm is involved in extensive networking with limited resource pooling. Here, firms recognise their codependence, but may realise faster development, innovation, and learning.

- In dynamic incubation, firms practice both resource pooling and knowledge seeking, needing to operate in a very open and ethical way with their partners. Thus, several potential risks must be managed.

Introducing the Service-Dominant Logic (SDL) paradigm Value co-creation is at the core of widely accepted SDL concepts developed by Vargo and Lusch (2016), in supporting business model innovation and service innovation (Maglio \& Spohrer, 2013). Table 1 presents five axioms associated with the SDL paradigm and our interpretation of them in a business incubation context. A model framing this viewpoint is shown in Figure 1.

Table 1. An interpretation of Service-Dominant Logic axioms in a startup business incubation context

\begin{tabular}{|c|c|}
\hline SDL Axiom & Incubation Context \\
\hline $\begin{array}{l}\text { Axiom 1/FP1: service is } \\
\text { the fundamental basis of } \\
\text { exchange. }\end{array}$ & $\begin{array}{l}\text { A service entity (an incubation } \\
\text { program of some kind) is responsible } \\
\text { for orchestrating the process of value } \\
\text { co-creation and for integrating } \\
\text { requisite resources. }\end{array}$ \\
\hline $\begin{array}{l}\text { Axiom 2/FP6: Value is } \\
\text { created by multiple actors, } \\
\text { always including the } \\
\text { beneficiary }\end{array}$ & $\begin{array}{l}\text { Value creation and delivery involving } \\
\text { multiple actors are orchestrated via } \\
\text { one or a set of customers (incubatee) } \\
\text { interaction events, with different kinds } \\
\text { of events supporting the customer at } \\
\text { different stages in the growth of a } \\
\text { startup firm }\end{array}$ \\
\hline $\begin{array}{l}\text { Axiom 3/FP9: All social } \\
\text { and economic actors are } \\
\text { resource integrators } \\
\text { Axiom 4/FP10: Value is } \\
\text { always uniquely and } \\
\text { phenomenologically } \\
\text { determined by the } \\
\text { beneficiary }\end{array}$ & $\begin{array}{l}\text { A service entity business model } \\
\text { identifies a value proposition } \\
\text { supported by social and economic } \\
\text { resources required to deliver value } \\
\text { Desired and realised outcomes are } \\
\text { determined by the beneficiary, but } \\
\text { other stakeholders will also have an } \\
\text { interest in value realised from their } \\
\text { own perspectives. One outcome is the }\end{array}$ \\
\hline $\begin{array}{l}\text { Axiom 5/FP11: Value co- } \\
\text { creation is coordinated } \\
\text { through actor-generated } \\
\text { institutions and } \\
\text { institutional } \\
\text { arrangements }\end{array}$ & $\begin{array}{l}\text { development of mutual trust. } \\
\text { A service-oriented ecosystem that } \\
\text { includes businesses, knowledge } \\
\text { diffusion, innovation, and technological } \\
\text { elements has infrastructure actors (e.g. } \\
\text { investors) aligned to an institutional } \\
\text { tenet that supports entrepreneurial } \\
\text { activities. }\end{array}$ \\
\hline
\end{tabular}




\section{A Triadic Actor View of Value Co-creation in Business Incubation Ronald Beckett and John Dalrymple}

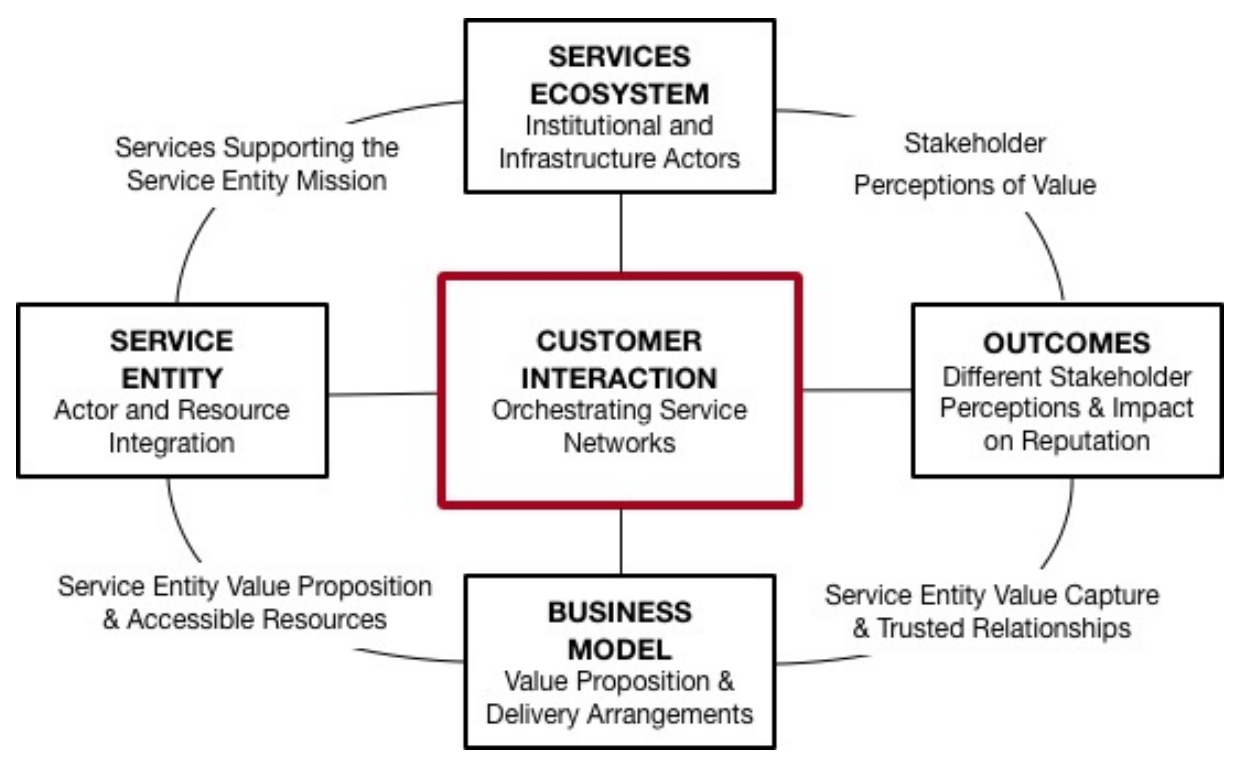

Figure 1. A Service Systems View of Customer Engagement

Note that we have included peripheral elements in this model that do not directly involve the customer:

- Access to ecosystem services supporting the Service Entity mission may be negotiated separately (for example, access to financing or infrastructure).

- Ecosystem actors have their own rationale for engagement and may expect to realise value outcomes independently of what the customer values.

- The Service Entity value proposition and access to resources negotiated with external stakeholders informs the Service Entity business model, drawing on customer value co-creation events.

-While customers seek value-in-use, the Service Entity also seeks value capture from transactions, along with outcomes that build trusted relationships with both customer and ecosystem actors.

\section{A triadic view of value co-creation}

From an SDL perspective, value is co-created by multiple actors, always including the beneficiary. In figure 1, value co-creation is facilitated via customer interaction events involving the service entity and service ecosystem actors. Research into triadic business relationships (Andreassen et al., 2018) has identified two modes of operation. In one mode, an intermediary performs a broker function having simultaneously associated dyadic relationships with buyers and sellers (for example, a realtor and an apartment seeker). In the other mode, an intermediary facilitates negotiations between a buyer and seller via a platform of some kind (Uber taxi services).

Drawing on the literature previously presented, we propose an interaction model where:

- Service ecosystem actors include investment actors, as they all seek to add value to their present operations in some way, whether contributing assets (financial, knowledge, infrastructure, technology) or time (for example, mentoring, advising, networking).

- Incubator actors participate in service entities of various kinds (providing courses, social events, coworking spaces) .

- Incubatee actors serve as the intended beneficiary, that is, startup firms, whether or not they are engaged in a coworking space or a formal incubation program.

A model showing both a triadic relationship and the associated dyadic relationships is presented in figure 2 . 


\section{A Triadic Actor View of Value Co-creation in Business Incubation Ronald Beckett and John Dalrymple}

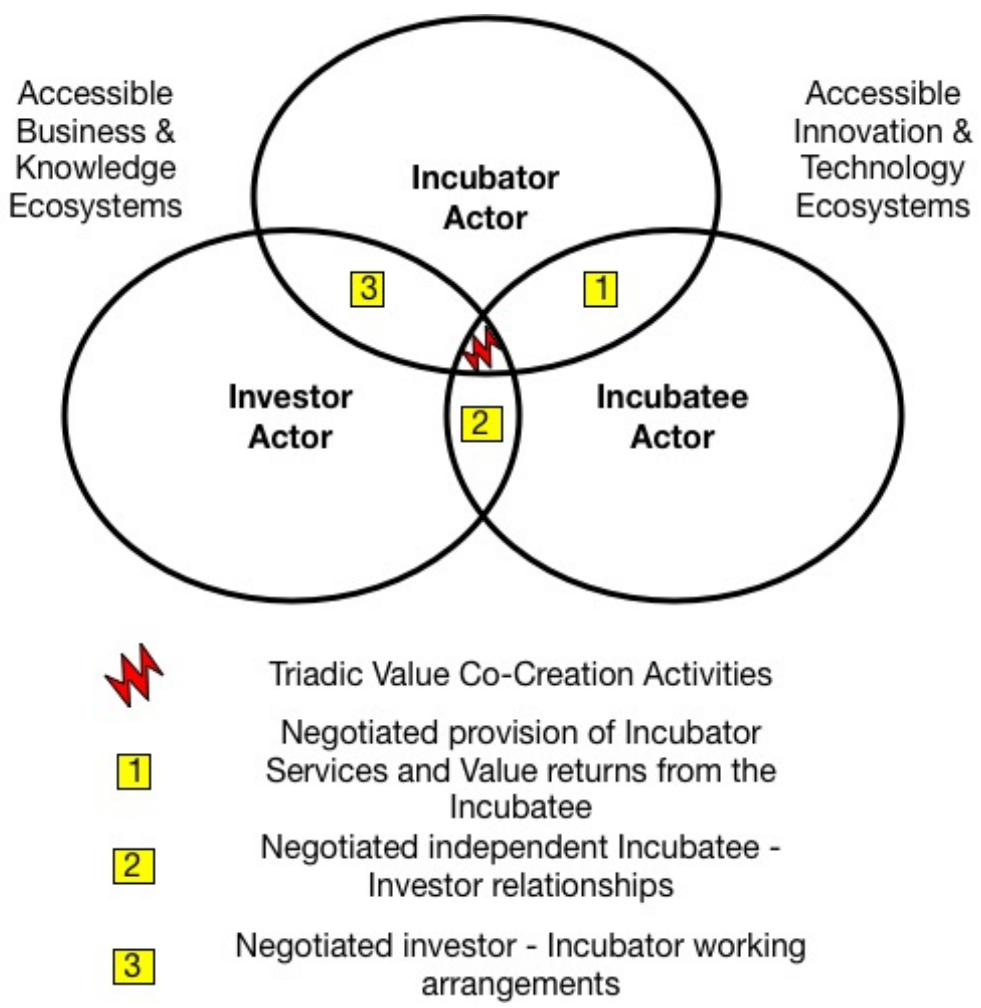

Figure 2. An incubation service triadic actor interaction model

In the context of figure 2, we represent the broader entrepreneur service ecosystem shown in figure 1 as four subsystems: business (finance, market, logistics, and human resources actors), knowledge (research, consulting, and education actors), innovation (idea exploration and exploitation actors) (Valkokari, 2015), and technology (technology platform and interconnected component actors) (Wareham et al., 2014). The rationale here is that some startups are primarily oriented towards one subsystem, for example, establishing a knowledge-based enterprise, but may also need to access the others, such as engaging the business ecosystem.

Dyadic relationships between incubator and incubatee actors have already been researched extensively, while dyadic relationships between investor and incubatee actors have also been explored, particularly in the venture capital literature. Dyadic relationships between incubator actors and investment actors have been explored to a lesser extent. It was suggested earlier (Von Zedtwitz \& Grimaldi, 2006; Bruneel et al., 2012) that an incubator may be classified according to its 'business model', which has been represented by university, regional, commercial, company-internal, and virtual models. We suggest this categorization could also be applied to identify classes of investment actor (for example, a university investor). We could then ask each of the actors in this ecosystem why they invest and how. In this sense, we would see a virtual model form through cooperation.

Vargo and Lusch (2016) suggest two SDL foundation principles, that 1) actors cannot deliver value, but can participate in the creation and offering of value propositions, and 2) value is co-created by multiple actors always including the beneficiary. We interpret this as requiring organised negotiation and delivery events, where the delivery of something based on a service entity value proposition facilitates a beneficiary realizing it as value-in-use. We recognize that value-in-use may not be realized until some time after the delivery event, but instead focus on delivery events themselves and their impacts.

This way of thinking leads us to the following propositions for gaining insights into incubation support practice: 


\section{A Triadic Actor View of Value Co-creation in Business Incubation Ronald Beckett and John Dalrymple}

- Incubation support practices should be framed in terms of the kinds of events managed (for example, course or workshop delivery, networking events, incubatee milestone events)

- Consideration of the roles of incubator, incubatee and investor actors in relation to each event should recognize that some actors may take laregly passive roles (for example, incubatee actors may endorse a grant proposal submitted by an incubator actor to an investment actor).

\section{The Research Approach}

Our research question is: how might an actor-centric view of incubation programs be used to draw out matters of context and practice? Yin (2014) suggested that a case study method is appropriate in considering such questions as how and why in a contemporary setting. Our unit of analysis is an incubation support service entity. We selected cases situated in one region, which means they are embedded in essentially the same business ecosystem. This region has seen recent job

Table 2. Overview of case study entities

\begin{tabular}{|c|c|}
\hline Case Study Entity and Goal & Brief Description of Activities \\
\hline $\begin{array}{l}\text { LaunchVic: a Victorian } \\
\text { state government } \\
\text { initiative aimed at } \\
\text { enhancing the scale and } \\
\text { scope of its regional } \\
\text { entrepreneurial } \\
\text { ecosystem. }\end{array}$ & $\begin{array}{l}\text { Rather than work directly with a } \\
\text { myriad of startup companies, this } \\
\text { program provides grants to established } \\
\text { incubation support actors of various } \\
\text { kinds to both build on regional } \\
\text { strengths, and address market failures. } \\
\text { The case highlights an investor view of } \\
\text { incubation programs. }\end{array}$ \\
\hline $\begin{array}{l}\text { Maroondah Bizhub: A } \\
\text { local government } \\
\text { initiative aimed at } \\
\text { supporting the } \\
\text { establishment and growth } \\
\text { of small / micro } \\
\text { businesses in its region. }\end{array}$ & $\begin{array}{l}\text { Home-based businesses represent a } \\
\text { large proportion of businesses in this } \\
\text { area. The local government authority } \\
\text { (Maroondah City Council) wishes to } \\
\text { encourage nascent entrepreneurs to } \\
\text { start businesses and enhance the } \\
\text { survival rate of already established } \\
\text { ones. In response to feedback from } \\
\text { local business leaders, a coworking } \\
\text { space was established. }\end{array}$ \\
\hline $\begin{array}{l}\text { Social Startup Studio: A } \\
\text { university research centre } \\
\text { initiative aimed at } \\
\text { enhancing the } \\
\text { sustainability of social } \\
\text { enterprises. }\end{array}$ & $\begin{array}{l}\text { The Swinburne University of } \\
\text { Technology's Centre for Social Impact } \\
\text { is supporting a small number of } \\
\text { startup social enterprises through the } \\
\text { stages of sustainable business } \\
\text { development. It includes researching } \\
\text { lessons learned along the way. }\end{array}$ \\
\hline $\begin{array}{l}\text { Innovation Precinct } \\
\text { Incubator: A university } \\
\text { initiative utilising startup } \\
\text { companies as one means } \\
\text { of facilitating technology } \\
\text { diffusion. }\end{array}$ & $\begin{array}{l}\text { The Swinburne University of } \\
\text { Technology has clustered together } \\
\text { manufacturing engineering, IT and } \\
\text { design centres of excellence, where } \\
\text { multidisciplinary development } \\
\text { projects can be hosted. This innovation } \\
\text { precinct includes a multi-purpose } \\
\text { incubator space. }\end{array}$ \\
\hline
\end{tabular}




\section{A Triadic Actor View of Value Co-creation in Business Incubation Ronald Beckett and John Dalrymple}

losses resulting from various causes and is promoting a culture of entrepreneurship in response. In two of the cases, a government entity is the primary investor, while the other two are a university.

A brief overview of the cases is shown in table 2. Each case was analyzed from the value co-creation viewpoint outlined above, which also facilitated cross-case analysis. We collected case data from websites, newsfeeds, and, where practical, publicly accessible internal reports supplemented with interview data. We then assembled and summarized the data in a secure university wiki project space to help organize the data in various ways.

\section{Findings}

\section{The LaunchVic case}

LauchVic, the primary investment actor, was established in 2016 to lead the enhancement of a globally connected startup ecosystem by supporting startups and investors in the State of Victoria. Up to mid-2019, more than $\$ 45 \mathrm{~m}$ AUD had been provided through 110 service entity grant projects.

The funded service entities performed four kinds of activity: researching the incubation ecosystem, organising awareness-raising events, managing calls for incubation service entity grants, reviewing outcomes, and celebrating successes. Research had indicated there were more that 120 incubation service entities in the State. The 2018-2019 annual report indicated there had been nine differently targeted calls for grant proposals, some targeting areas of strength (for example, the health sector) and some targeting market failures (for example, regional and aboriginal incubators).

In terms of incubatee actor selection and their ambitions, research indicated there were more than 2,700 startups in Victoria. While there was considerable diversity in the target market segments, the largest $(44 \%$ total) were in the health, media/entertainment, social enterprise, and commerce sectors.

\section{The Maroondah Bizhub case}

A local government in Australia that wishes to support startup firms and enhance the sustainability and growth prospects of small/micro businesses in its region constitutes the primary investment actor. Rather than funding or structured programs, Maroondah Bizhub offers the provision of services and a conveniently located coworking facility. Bizhub draws on external knowledge via specialist consultants, and state government service providers. In 2019, an independent assessment of value-added indicated the Bizhub had contributed $\$ 19 \mathrm{mln}$ to the local economy over the preceding 3 years.

The service entity, Bizhub, organises knowledge sharing events to support startups and help grow small businesses, along with managing the co-working facility. It has a dedicated co-working space manager and staff that organise events. More than 650 clients have attended events over the preceding three-year period. Various levels of co-working space access offer a range of full time, full service to casual membership, where access to the space or meeting rooms can be booked on a day-to-day basis. 115 co-working clients all receive a monthly newsletter on forthcoming events, opportunities, and success stories. The co-working clients rarely attend general information events, citing problems with time or timing, while individual sessions with a subsidised 'expert in residence' (business coach) may be booked.

The co-working clients are mostly professional or IT services firms employing 1-5 people. They cite coworking benefits like those identified by other researchers. Although some networking events enable mingling and networking, otherwise few instances arise for synergistic relations to develop. A 'show and tell' series of events was planned for Maroondah Bizhub in 2020 to help clients learn from each other, which was underway until the covid-19 pandemic emerged. Clients wishing to apply for a government grant may also receive assistance on request.

\section{The Social Startup Studio case}

The investment actors in this case were the Swinburne Research Centre for Social Impact (CSI). It is networked with five other similar centres throughout Australia and with financial services firms that establish and manage socially responsible investment portfolios. The CSI engages Startup Studio client firms in an action research program. It has been expanding its portfolio of research projects, and the financial services firms are looking for startup investment opportunities. The CSI also has developed strong social services industry connections associated with its research work.

A Startup Studio Director with prior social enterprise management experience manages the program and external links, a studio manager is responsible for dayto-day client interactions, and a third manager is 


\section{A Triadic Actor View of Value Co-creation in Business Incubation Ronald Beckett and John Dalrymple}

responsible for overseeing the co-working space that is available for clients within the research centre. Startup Studio clients are advanced through foundational studies, focused on activity detailing, business modelling, and social enterprise construction stages of development. This draws on educational material from a master's program offered by CSI with links to subject matter experts negotiated on a needs basis.

In 2019, an initial batch of five Startup Studio clients (incubatees) was selected from 38 registrations of interest. An earlier CSI study of the Victorian social enterprise sector had indicated that startups commonly last no more than 3 years, or have difficulty growing and scaling. The incubatee firms wish to establish a strong foundation for their enterprises to avoid this situation with the help of professional guidance.

\section{The Innovation Precinct case}

The investor actors are again Swinburne University, represented by the Deputy Vice Chancellor Research and Development and leaders of the university's "three pillars [as] centres of excellence": the Factory of the Future, the Digital Innovation Lab, and the Design Factory Melbourne (the latter which is one of seven similar collaborating operations around the world). Each of the "pillars" has an extensive network of industry contacts.

The key incubator actors are the Director of the Innovation Precinct, the Director of Commercial Innovation Programs, and the Director of Innovation and Entrepreneurship (who has direct experience in establishing and growing startups). The Precinct is regarded as providing an innovation ecosystem that supports both large and small projects that involve both industry and student engagement.

The incubator program offers access to a co-working space and an entrepreneur-in-residence. A variety of services are offered as different kinds of events, along with a program of forthcoming events published on the website. These include: (a) a startup lean canvas workshop oriented towards taking an idea to market, (b) a five-week pre-accelerator program, (c) a 12-week accelerator program aimed at helping startups become 'venture ready'. Selected participants receive some funding, access to experienced mentors, a co-working space and masterclasses or workshops for an extended period. (d) various 'pitch' competitions held in the facility.
The incubatee actors are generally Swinburne students, staff or alumni, and participation in each type of event has its own selection criteria. Incubatees have opportunities to learn from each other through 'pitch' events and workshop activities, and they may co-create artefacts of value through engagement with a centre of excellence investor in the program. For example, a product prototype may be manufactured using Factory of the Future 3D printing facilities.

\section{Discussion}

Investment actors may offer funding (LaunchVic case), access to specialist knowledge (Social Startup Studio and Innovation Precinct cases), innovation support (Innovation Precinct case), access to physical assets such as co-working spaces (all except LaunchVic), or prototype production facilities (Innovation Precinct case). Investment actors in all cases expect some form of return on their investment. It may be enhanced regional wealth generation and distribution, better employment opportunities, enhanced engagement with social issues, new knowledge generation, or simply new ideas and professional networking.

Incubator actors need to actively engage with investors and demonstrate the benefits of incubation realized (all cases). Incubator actors may facilitate investment actor - incubatee actor engagement (Social Startup Studio and Innovation Precinct cases). Incubator actors may offer access to a range of services that incubatees can choose from (Maroondah Bizhub and Innovation Precinct cases), or bundled packages of services (Social Startup Studio).

Most startups are still in the early stages of development. Inexperienced entrepreneurs especially may prefer to join a structured program (Social Startup Studio case). Not all startups are always in a growth phase while stabilising current operations, but may find operating from a co-working space beneficial (Maroondah BizHub case). Not all incubator offerings are equally valued. Startups may strategically choose some support offerings, while rejecting others (Maroondah BizHub and Innovation Precinct cases). Matters of time allocation and timing may impact what is accessed and when (Maroondah BizHub and Innovation Precinct cases).

We argue that incubators are only sustainable first, if they attract suitable clients, and second, if they retain 


\section{A Triadic Actor View of Value Co-creation in Business Incubation Ronald Beckett and John Dalrymple}

investor support. Chase and Webb (2018) have observed that very few incubators are self-sustaining business operations. It has been shown that not all startup firms may benefit from engagement with an incubator, or that they may move from one kind of incubator program to another as their needs change (Lukosiute et al., 2019). Incubator usage thus depends on the prior experience of a startup team, what they need to learn at a given point in time, and the nature of any innovation being introduced. In addition, some startups may realize value from their engagement by combining resource-seeking and knowledge-seeking behaviour in different ways, thus influencing the type of interaction they have with an incubator (Hughes et al., 2007). Whilst an incubator may have a client selection process, clients will usually have incubation service entity selection options.

From an incubator actor perspective, different kinds of support may be sought by different incubatee clients at different stages of their enterprise's development. This may require the incubator actor to flexibly access a network of actors and resources. In a networked environment, it has been suggested that an enterprise can improve value co-creation opportunities by adopting business models that have a "high degree of internal and external configurational fit" (Nenonen \& Storbacka, 2010). In the model presented here, this would involve harmonizing the interests of three kinds of generic actor.

\section{Concluding Remarks}

We return then to our research question: how might an actor-centric view of incubation programs be used to draw out matters of context and practice? Utilizing the Service-Dominant Logic paradigm (Vargo \& Lusch, 2016), we found that:

- An incubator actor is viewed as a service entity integrating actors and resources to offer a value proposition to its clients. Whilst SDL has been widely used as a tool in a variety of business studies, it has rarely (if at all) been used in incubator studies, and we offer this as a contribution to incubation theory.

An incubator program provides an environment where clients can mature and grow. It may be associated with the provision of a co-working space. Whilst some firms may 'graduate' from an incubator program, continuing growth may need to take place within the incubation environment. Value is co-created not only through service entity-client interaction, but also in concert with an external services ecosystem (see figure 1). We have represented this ecosystem aspect of interaction as being provided by an investor actor(s) who also has a particular engagement rationale.

In this paper, we explored incubation instances via four illustrative case studies that offer access to some form(s) of asset - financial, knowledge, innovation infrastructure or technology assets - delivered via oneon-one negotiations, courses, workshops, or external relationships. In reflecting on our case studies, we saw an analogy with a department store stocked with commonly needed items organised in different sections. Each section relates to the stage of development of a client. Whilst all stores may stock the same basic items, some may specialise, for example, having offerings associated with one technology or development stage. The store may also operate as a passive entity, where clients choose what they need when they need it (the Maroondah Bizhub case), or offer guidance, helping clients with appropriate selections and advice about how to use each selection (the Social Startup Studio case). There may be an emphasis on access to financial resources (the LaunchVic case), or to innovation or technology resources (the Innovation Precinct case).

It is thus up to the individual client (incubatee actor) to determine what they need and when. Nevertheless, in every visit, which we view as an event, something of value must be exchanged for whatever is accessed. Payment may be immediate (for example, payment for training) or may be deferred (for example, stimulating regional employment). What is valued will also depend on the store owner (investor actor) - it may be economic or social capital, access to additional assets, or some combination of these things.

From a practitioner perspective, an actor-centric view may offer greater appreciation of startup incubation dynamics than a business model view. What services are provided in which incubators and why? Incubation support may be framed as a series of value co-creation events, but how is value co-created, and who is involved in each kind of co-creation event? In practical terms, if one of the actors does not see any value in engagement in any given incubator, then no events will take place there. One limitation of the research presented here is that it only considers two kinds of investment champion - regional governments and universities - whereas other types have been noted in the literature: commercial, company internal, and virtual (represented as various 


\section{A Triadic Actor View of Value Co-creation in Business Incubation Ronald Beckett and John Dalrymple}

kinds of business models). Another limitation relates to the cases themselves. While we collected enough detail on each case to support a set of single case study papers, this would have required more space than available here.

\section{References}

Andreassen, T.W., Lervik-Olsen, L., Snyder, H., Van Riel, A.C., Sweeney, J.C. and Van Vaerenbergh, Y. 2018. Business model innovation and value-creation: the triadic way. Journal of Service Management, 29(5): 883-906.

Autio, E., Kenney, M., Mustr, P., Siegal, D., and Wright, M. 2014. Entrepreneurial innovation: The importance of context. Research Policy, 43: 1097-1108.

Bosma, N., Van Praag, M., Thurik, R., and De Wit, G. 2004. The value of human and social capital investments for the business performance of startups. Small Business Economics, 23(3): 227-236.

Bruneel, J., Ratinho, T., Clarysse, B., and Groen, A. 2012. The Evolution of Business Incubators: Comparing demand and supply of business incubation services across different incubator generations. Technovation, 32(2): 110-121.

Chandra, A., and Fealey, T. 2009. Business incubation in the United states, China and Brazil: a comparison of role of government, incubator funding and financial services. International Journal of Entrepreneurship, 13: $67-86$

Chase, I and Webb, J. 2018. Business Incubator and Accelerator Sustainability. Business Innovation \& Incubation Australia. Accessed 22 Nov 2018: http://businessincubation.com.au/wpcontent/uploads/Business-Incubator-AcceleratorSustainability-BIIA-31518-1-3.pdf

Dee, N., Gill, D, Weinberg, C. and McTavish, S. 2015. Startup support programs: What's the Difference? https://www.nesta.org.uk/report/startup-supportprogrammes-whats-the-difference/

Eriksson, P., Vilhunen, J. and Voutilainen, K., 2014. Incubation as co-creation: case study of proactive technology business development. International Journal of Entrepreneurship and Innovation Management, 18 (5-6): 382-396.

Fernández Fernández, M.T., Blanco Jiménez, F.J., and Cuadrado Roura, J.R. 2015. Business incubation: innovative services in an entrepreneurship ecosystem. The Service Industries Journal, 35(14): 783800.

Hughes, M., Ireland, R.D., and Morgan, R.E. 2007. Stimulating dynamic value: Social capital and business incubation as a pathway to competitive success. Long Range Planning, 40(2): 154-177.
Lukosiute, K., Jensen, S., and Tanev, S. 2019. Is Joining a Business Incubator or Accelerator Always a Good Thing? Technology Innovation Management Review, 9(7): 5-15.

Maglio, P.P., and Spohrer. J 2013. A service science perspective on business model innovation. Industrial Marketing Management, 42, no. 5: 665-670.

Nenonen, S. and Storbacka, K. 2010. Business model design: conceptualizing networked value cocreation. International Journal of Quality and Service Sciences, Vol. 2, No. 1: 43-59.

Ranjan, K.R., and Read, S. 2016. Value co-creation: concept and measurement. Journal of the Academy of Marketing Science, 44(3): 290-315.

Rice, M.P. 2002. Co-production of business assistance in business incubators: an exploratory study. Journal of Business Venturing, 17(2): 163-187.

Valkokari, K. 2015. Business, Innovation, and Knowledge Ecosystems: How They Differ and How to Survive and Thrive within Them. Technology Innovation Management Review, (5) 8: 17-24.

Vargo, S.L. and Lusch, R.F. 2016. Institutions and axioms: an extension and update of service-dominant logic. Journal of the Academy of Marketing Science, (44): 5-23.

Von Zedtwitz, M., and Grimaldi, R. 2006. Are service profiles incubator-specific? Results from an empirical investigation in Italy. The Journal of Technology Transfer, 31(4): 459-468.

Yin, R.K. 2014. Case Study Research Design and Methods, Fifth Edition. Sage Publications, Thousand Oaks, California. (ISBN 979-1-4522-4256-0) 


\section{A Triadic Actor View of Value Co-creation in Business Incubation Ronald Beckett and John Dalrymple}

\begin{abstract}
About the Authors
Ron Beckett is an industry practitioner with more than 30 years of experience in the implementation of creative change and innovation management in Aerospace and Manufacturing. He frequently works at the academia-industry interface, with a focus on Learning to Compete. Ron is an Adjunct Professor at Swinburne University, and he has held similar appointments at several other universities. He has authored or co-authored more than 100 conference papers, journal articles, and book chapters related to the pursuit of best practice in extracting value from innovative ideas, knowledge management, and effective collaboration implementation.

John Dalrymple holds a BA (Hons) from the University of Stirling and a $\mathrm{PhD}$ from the University of Strathclyde in Scotland where he worked with the Scottish Enterprise Foundation to improve the performance of small and medium-sized companies. He was Founding Director of the Centre for Management Quality Research at RMIT University. John, the staff, and students of the Centre were regular recipients of "Best Paper" awards at international conferences. His publications have attracted more than 1100 citations to date. John was the Editor of the Quality Assurance in Education journal from 2003 until 2019. He has supervised over $20 \mathrm{PhD}$ candidates to successful completion. In October 2018, John was presented with the J. M. Juran Award by the Australian Organisation for Quality.
\end{abstract}

Citation: Beckett, R., and Dalrymple, J. 2020. A Triadic Actor View of Value Cocreation in Business Incubation. Technology Innovation Management Review, 10(8): 27-37.

http://doi.org/10.22215/timreview/1379

(cc) BY

Keywords: Incubators, service entities, co-working, knowledge-sharing, stakeholders, service ecosystems, investors, value co-creation, servicedominant logic, triadic relationships. 